\title{
Modern Austrian Novel: Endless Wanderings in the Labyrinths of Kafka's Castle
}

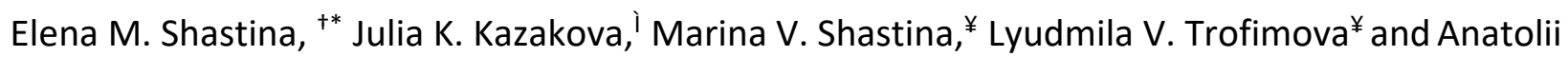
M. Borisovi

\section{Abstract}

The purpose of the article is to discuss the perception of Kafka's The Castle (Das Schloss, 1922) in the novels The Peaches Killers (Die Pfirsichtöter, 1972) by Alfred Kolleritsch, Among the Bieresch (Bei den Bieresch, 1979) by Klaus Hoffer and Into the Castle (Ins Schloss, 2004) by Marianne Gruber. The reference to the writers and their works is no coincidence; preference is given to the artists whose creative manner reflects the most fashionable trends in Western European literary process - from avant-garde to postmodernism. The authors of the article deliberately arrange the analysed works in chronological order to follow the stages in the development of German postmodernism which originates from modernist literature. The universal Kafkaesque discourse suggests the existence of direct and inverse connections between the author and the reader, the extra-textual tradition and reality. The article focuses on the narrative strategies of Austrian avant-garde (Kolleritsch), analyses postmodern discourse (Hoffer, Gruber) in the Austrian literature of the second half of the 20th and early 21st centuries, reveals signs of typological similarity between the novels by Kafka, Kolleritsch, Hoffer, and Gruber, which seems productive for understanding the influence of modernist literature on the development of the postmodern paradigm in the German-language literary space. Austrian literature, to a greater extent, is fraught with the search for new forms of self-expression rather than with the artistic "overcoming the past" - the awareness of collective guilt. It brought to the forefront the authors in whose works the age of change was reflected. Literary avant-garde has been replaced by authors who skillfully "play" with the previous culture and establish a dialogue with the present. The comparative methodology is to reveal the perception of "Kafkaesque discourse" in modern Austrian literature and to draw conclusions about the ways authors treat ontological questions.

Keywords: Kafka, Kolleritsch, Gruber, Hoffer, Austrian Avant-Gardism, Kafkaesque Discourse, Postmodernism

\footnotetext{
${ }^{\dagger}$ Holder of an Advanced Doctorate in Philology, Head of German Philology Department. Kazan (the Volga Region) Federal University, Elabuga Institute

${ }^{*}$ Corresponding Author, Email: shastina@rambler.ru

'PhD in Philological Sciences, Senior Lecturer at the Department of English Philology and Cross-Cultural Communications, Kazan (the Volga Region) Federal University, Elabuga Institute, Email: kazakova696@gmail.com

$¥$ PhD Student at German Philology Department,Kazan (the Volga Region) Federal University, Elabuga Institute 'PhD in Pedagogical Sciences, Associate Professor at the Department of English Philology and Cross-Cultural communications, Kazan (the Volga Region) Federal University, Elabuga Institute, Email: anatboris@rambler.ru (C) 2019 Shastina et al. This is an Open Access article distributed under the terms of the Creative Commons Attribution License (http://creativecommons.org/licenses/by/2.0), which permits unrestricted use, distribution, and reproduction in any medium, provided the original work is properly cited.
} 


\section{Introduction}

Kafka's phenomenon (Franz Kafka, 1883-1924) has been the subject of numerous studies; even a special term Kafkaesque has come into use for designating the artistic world created by the writer. In this world, the ordinary coexists with the fantastic when the boundaries between the real and the surreal become blurred when the absurdity of existence becomes a norm of daily existence. "Kafkaesque discourse" is universal, one can never be sure of where and when the action takes place. Eventually, a chronotope appears which can be "refined" as "always" and "everywhere".

Literary creativity is always based on a specific artistic model, the features of which are determined by the universal laws of the text as a means of information communication on the one hand, and on the other hand, by following certain national or foreign traditions and by artistic preferences of the author who creates a personal discourse. In this sense, the discourse is a broader concept than the text because it includes all the stages of creating a literary work: from the author's idea of establishing relationships with the reader (Bozhkova et al., 2019).

Kafkaesque discourse is "original, sharply singled out, even against the background of world literature, aesthetic system" (Sedelnik, 2009, p.282). Kafka is unique because he is always modern; his texts are inexhaustible in their "ambiguity" and open to comprehension (Eco, 2004, p.38), and the questions the reader tries to find answers to together with the author are eternal.

In Kafka's unaccomplished novel The Castle, first published in 1926, two years after the death of the writer, the protagonist, a land surveyor $\mathrm{K}$. comes to the village managed by the castle to take the promised position of a surveyor (Kafka, 1991, p.16). All attempts by K. to approach the castle prove to be in vain. The castle, an embodiment of absolute power, remains unattainable. This is a "parabola novel about the meaning of life, more precisely, the impossibility of giving to human life a more or less definite meaning" (Sedelnik, 2009, p.302). The apparent simplicity of the plot, its emphasised cyclicity and fragmentation, the incompleteness of action and hopelessness is what lies on the surface, and the reader familiar with Kafka's work, as a rule, copes with it without much effort. Then everything gets much more complicated as Kafkaesque discourse starts to "act", thoroughly metaphorical, filled with special symbolic ambiguity. Kafka's "reality" is tempting; his artistic world, "dreamily unsteady", has an inexplicable appeal and "every new reading of The Castle is a new drawing of the way in which the reader's consciousness wanders in the labyrinth of the novel" (Belobratov, 2007, p.471472).

Beyond the scope of this article are numerous interpretations of Kafka's novel. What is significant about them is that The Castle is played out in the spirit of the "new time" by modern authors (Yari and Afrougheh, 2013; Harman, 2002; Major, 2011; Friedlander, 2016).

This work traces a variety of connections between the poetics of Kafka's The Castle and the works of contemporary Austrian writers and researches the theme of perception of Kafka based on new literary material. The conceptual basis of the work is the perception and interpretation of Kafkaesque discourse as a motive, a theme and an ideological problem in the novels by Kolleritsch, Hoffer, and Gruber. All three novels reveal numerous allusions to The Castle by Kafka, which makes it possible to trace the "intertextual dialogue" in the Austrian literature of the 20th and 21st centuries and indicates the postmodernist tendencies originating within the literature of modernism (Kaszynski, 2017). The following section discusses the methods deployed for this research.

\section{Methods}

The methodology that guides the authors of the article is based on the traditional historical and cultural approach to literature which combines the experience of classical literature studies, 
both Russian and foreign. The artistic nature of postmodern works determines as the most appropriate strategy a combination of complementary approaches of various methodologies: literary-theoretical, historicalliterary, hermeneutical, intertextual, as well as structural-semiotic elements. The postmodern paradigm in the literature of German-speaking countries manifested itself much later than in other European countries, which is primarily connected with the acute problem of "overcoming the past" (Vergangenheitsbewältigung). Austrian literature, being burdened with a "guilt complex" to a lesser extent, united in its ranks representatives of literary avant-garde and postmodernism. Signs of a postmodern attitude are intertextuality, which involves the use of literary predecessors' art codes and quoting someone else's text, borrowing the mythological type of world modeling, including elements of an ironic game and various kinds of hoaxes in the text, and, as a result, focus on the general reader. All these "postmodern markers" fully reveal themselves in the analysed novels.

The use of comparative methodology makes it possible to discover the mechanism of the perception of Kafkaesque discourse and to consider the features and laws of the figurative structure of the artistic text. The historical and cultural approach will allow stating a typological commonality of the works by Kolleritsch, Hoffer, Gruber. Motivation analysis is called upon to reveal meanings not only relevant for each writer but also dominant in the context of the epoch.

Based on the principles of communication between literary texts, the authors of the article resort to the method of intertextual analysis to find out the semantic connections of Kafkaesque discourse in which the original aesthetic system created by Kafka refracts with the works of modern authors. The methods of linguistic stylistic analysis are traditionally understood as a combination of various methods of analysing a text and its language means. Taking into account the peculiarities of the individual style of each of the authors contributes to a more thoughtful reading of their works. The results are discussed in the next section.

\section{Results}

A priori, Kafka's poetics has influenced the world literary process. Kafkaesque discourse by virtue of its universality remains relevant, demonstrates at every subsequent stage in the development of literature the ability to acquire additional meanings by transforming and modifying.

Kafkaesque discourse as a cross-cutting motive reveals itself in the novels of Kolleritsch, Hoffer, and Gruber, each of which suggests numerous allusions to the castle as a kind of hierarchical system in which the relationships of representatives of various social classes "demos" and "okhlos" are laid. Kafka's castle is the embodiment not only of the state's power but also of the power of the strong over the weak in general. The anonymity of the power introduces the Castle as a totalitarian system, the magnitude of which Kafka prophetically discovered in reality surrounding him.

The reception of Kafka's novel The Castle in Austrian literature of the 20th and 21st centuries is a vivid confirmation of this. The Peaches Killers by Kolleritsch (Kolleritsch, 2003), Among the Bieresch by Hoffer (Hoffer, 2017) and Into the Castle by Gruber (Gruber, 2004a), which marked the change of cultural paradigms (modernism avant-gardism - postmodernism), allow discovering the originality of the authors' intention in creating a typological picture of the "new reality", preserving and continuing the traditions of Austrian literature.

\section{Discussion}

\section{Alfred Kolleritsch}

The events in the novel by Kolleritsch, "a patriarch of Austrian avant-gardism", develop near a castle lost in the woods. Even though there are no toponyms in the novel, its "austrianness" is visible. For many years, Austria with its corporate "culinary and advertising facade" (Mikhailov, 2009, p.15) had remained "symbolically closed on all sides by high mountains, a country in which strict norms and 
conservative views reigned" (Plakhina, 2010, p.8). The castle is the embodiment of a hierarchy that has not changed for centuries. On the top of this hierarchy, there are the count and participants in the repast, eighteen eaters sitting at the "banquet table of the nobility" (Kolleritsch, 2003, p.20) and discussing the topic of life "ennobling". Kolleritsch, following Kafka, creates a closed system with signs of a totalitarian society where strict hierarchy and control are absolute.

Kolleritsch experiments with the language; the speech of the characters appear in the form of a simulated language reality often devoid of referential content. In search for "new forms", Kolleritsch attempted to fill philosophical models and structures with his own content (Bartsch, 2016).

Kolleritsch's inhabitants of the Castle (the "tops"), the count, the countess, the duke, the philosophical guests, the participants in the "platonic feast", just as in Kafka's novel, are opposed to the "lower classes" - servants, who serve the masters by faith and truth. Social injustice is the basis of the whole life arrangement. "The masters live in the bosom of being that doesn't create and isn't created, they live in the castle that was given to them from the beginning of time" (Kolleritsch, 2003, p.31). The inhabitants of the castle are celestials because only they can appreciate the results of culinary art and gastronomy "Equality of the gullet is a lie and an absurdity" (Kolleritsch, 2003, p.32). "Gastronomy is the mother of the class division. It rules the meetings and festivities of the masters. It despises plebeian mouth" (Kolleritsch, 2003, p.32).

Everything goes on smoothly; the castle is an inviolability that no one dares to encroach on, even in thought, so the act of a faithful servant who planted peach trees on his stead violating the will of the Castle rulers is comparable to a seismic push, a harbinger of future changes. The Countess with a handsaw becomes a "peach killer": "Everything that lived not according to her law, dared to create, is doomed to death" (Kolleritsch, 2003, p.38).
At the end of the novel the castle comes to complete desolation for many reasons, the most obvious being the war, as a result of which the castle is devastated and destroyed. The other reason for the existential nature is the transformed consciousness of people, an unthinkable life without the castle that has sunk into oblivion. Kafka's opposition Castle-Village persists throughout the novel; the alleged fate of the surveyor K. is tragic. Kolleritsch still has the hope that a new life may start "when all are free, all are equal" (Kolleritsch, 2003, p.234). The Peaches Killers is an open end novel that can be read optimistically.

\section{Klaus Hoffer}

Hoffer, a writer and translator from English, to study Kafka's fantastic context refers to "methods of confusion" (Methoden der Verwirrung) (Hoffer, 1986). Hoffer, following Kafka, confuses his narrative in such a way that the reader finds it difficult to give an exact answer to the most obvious questions about the place and what is happening in the novel. It is not clear who the Bieresch are and what they actually do. Their main occupation is philosophising, explaining all and everything to each other, "We don't live, we explain life" (Hoffer, 2017, p.66). Orthail considers Hoffer's book to be one of the first works of Germanlanguage literature in which the entry into the postmodern context is imprinted (Ortheil, 1994, p.134).

The novel begins with the story of the protagonist, a young man named Hans, about his life experience acquired far from his home: "I spent the summer in a remote province in the east of the empire, with my older relative, a widow who has recently got widowed. The days in this flat scorched land were brief, fleeting; they disappeared from memory when dry, cold nights would fall like the glaze on pots cracks the skin of a deceased person"(Hoffer, 2017, p.9). This preamble in the most concise form introduces the reader to the contents of the book, at first glance a banal story that has much in common with a "travel novel built on a series of episodes" (Reiseroman als Episodenroman) (Beckermann, 1986, p.429). 
Obviously, this is a retrospective view of the protagonist on the events related to his stay among the Bieresch. According to the traditions of the Bieresch, Hans as a senior relative has to replace his deceased uncle for a whole year. Hans seeks to know himself; in the Bieresch country, both time and space are different. Real place names coexist with fictitious names. No less confusion arises about the Bieresch themselves, who appear "as a closed community with its mythology, a system of sacred texts, archaic customs and rituals" (Gladilin, 2010, p.111). The Bieresch is the name of the impoverished farmers, who in the 19thcentury were engaged in cultivating the leased landlords' land in Pannonia, in one of the federal lands of Austria, lying on the border with Hungary and Croatia. The land "at the edge of the world" becomes the scene of action. Stagnation, the absence of any movement forward, and desolation are only a general background.

The Deformation of space gives the sensation of "moving in a non-Euclidean world, mobile and stretchable" (Eco, 2014, p.157). "The ground is unsteady under the traveler's footsteps like a swampy path at the water's edge". It makes the traveler feel dizzy; it is kind of "land seasickness" (Hoffer, 2017, p.62). Hoffer's novel is built according to the laws of postmodern intertextuality, as evidenced by the abundance of the references to works of world literature (Marguez, 1970; Borges, 1962; Handke, 1970; Kafka, 1991 and others). Gladilin points out the distinctive features of Hoffer's post-modern novel as "increased intellectualism", "heaviness", and accentuated" ontological pessimism" (Gladilin, 2012, p.22).

The author resorts to a language game; it is clearly reflected in the "legend of the names", according to the rule of which all the names of the community members are to be arranged so that as a result of their stringing a complete story can be made. Gladilin points out the distinctive features of Hoffer's post-modern novel like "increased intellectualism", "heaviness", "ontological pessimism" as compared to the works of other authors (Gladilin, 2012, p.22).
Hoffer's novel and Kafka's The Castle are brought together by the atmosphere of despair which leads to nowhere. Hans, a character of Hoffer's novel, like Kafka's land surveyor, starts a long journey through the God-forgotten land; the journey becomes a self-sufficient value. Unlike the hero of The Castle, Hans, in order to adapt to a new life "floats with the stream" obeying the circumstances, despite the fact that everything in this alien world "looked faked and artificial" (Hoffer, 2017 p.102).

\section{Marianne Gruber}

Gruber's novel Into the Castle is more transparent in terms of revealing allusions to Kafka's The Castle. From the very title, the author starts her game with the reader in the postmodernist spirit. It is "a satellite novel spinning in the orbit of Kafka's The Castle, still remaining an authentic work in the style of postmodernism" (Kachorovskaya, 2010, p.131). Gruber through the "new hero" plays with the "new reader" who is endowed with imagination preventing from getting lost in the labyrinth of Kafka's text, as a result "a parable about a modern man in the current situation is told" (Gruber, 2004b, p.330).

The reader deals with a novel containing a set of signs that refer it to the postmodern artistic paradigm. Firstly, the novel is thoroughly intertextual, suggesting an analogy with Kafka's Gregor Zamza, who turned one morning into a helpless insect (The Metamorphosis). At the beginning of the novel Into the Castle, the main character is homeless and has no human sympathy, sleeps in a pile of rags, which like a "shell" binds his body. Gruber introduces into the text of the novel a reference to Kafka's autobiographical prose, in particular, to his diaries.

Secondly, Gruber's reference to the frequently used motif of duality testifies to the typological affinity of postmodernist German-language literature with the literature of romanticism.

The image of the protagonist is complemented by his counterpart, double-ganger: "So, a first $\mathrm{K}$. left empty-handed. But then I, the second K., obviously arrived here some day" (Gruber, 
2004a, p. 100). The co-existence of the first K. and the second $\mathrm{K}$. is "a new reality" created and played up by Gruber. "I'm not a surveyor," retorted K., "just Josef K." (Gruber, 2004a, p. 28). Such a self-identification of the hero also disorientates the reader, who expects that it is the surveyor K.

Thirdly, the methods of "lucid narrative" are intended for the mass reader. On the one hand, Gruber in parable form "in the spirit of Kafka" talks to the intellectual reader; on the other hand, she revives the story with a fairy tale about the "good young man", who on his way to the Castle encounters obstacles. The road to the Castle is bewitched; the hero tries to overcome all the trials in order to achieve his goal. Both heroes fight with the snow-storm; snow is traditionally associated with death. At the end of the earthly journey, "the snow erased all signs, it poured more and more, sweeping all around, absorbing all the sounds, and finally, there was only the breath of $\mathrm{K}$. and the heart beating in his chest. He tried to breathe as quietly as possible, breathing in and out without sound, tried to calm the rapidly beating heart. Hush, he thought. You have to be able to lose, so you've lost. He was breathing easily and whispered to himself: quieter, quieter! - waiting for the invasion of snow"(Gruber, 2004a, p.326).

Fourthly, the postmodern principle of the game places the protagonist and the reader on an equal footing. Kafka's reader wanders along with the hero in the labyrinth of streets; eventually, it turns out that no one road leads to the Castle. The motif of the labyrinth in Gruber's novel transforms acquiring a new meaning. The reader deals with myth-making. The ending of the novel "Before him was a new world" (Gruber, 2004a, p.326) is crossed out, making rewriting of the story impossible, Into the Castle is pessimistic; the hero is doomed, he aspires to the Castle to see the futility of his attempts, to get an answer that initially cannot be positive. "He, the modern Job, sees how beautiful the Creation is, but also sees that people on earth suffer grievously. And for this he stubbornly and sternly demands the answer, insisting that there is no justification for this" (Gruber, 2004a, p.344). The hero does not count on mercy, he rejects it. For him, only death can be a favor; he is deprived of hope, but he does not give up.

\section{Conclusion}

The works analysed in the article are intentionally arranged in chronological order to reflect the stages in the development of German-language postmodernism originating from modernist literature. Attempts to attribute Kafka to any particular literary trend are counterproductive due to the uniqueness of his artistic world. At the same time, it should be noted that Kafka's The Castle has many signs of modernistic worldview associated with the disintegration of the integrity of the world perception, with ironic skepticism and total pessimism. The poetics of Kafka's The Castle, a landmark novel of the 20th century, influenced the modern Western European literary process. Austrian literature tends to search for new forms of self-expression rather than for artistic "overcoming of the past" - the awareness of the collective guilt. It brought to the forefront the authors whose works reflected the era of change. The authors who skillfully "play" with the previous culture build a dialogue with the present, thus replacing literary avant-garde. Kafkaesque discourse remains an inexhaustible resource for the postmodernists.

The typological similarity in the novels of Austrian writers points to the continuity of traditions testifying to the originality of Austrian literature, to the authors' intention to solve existential problems "in Austrian way" which is expressed in the search for Austrian identity, in an ambivalent nature of perception of the historical past and a tendency towards selfcriticism, debunking of historical myths, as well as in language experimentation, etc. The identification of the mechanisms of perception of Kafkaesque discourse in the works of modern authors like Kolleritsch, Hoffer and Gruber is a promising line in modern literary studies.

\section{References}

Bartsch, K. (2016). Alfred Kolleritsch [Electronic resource]. Kurt Bartsch and Gerhard Melzer (Hrsg.). Accessed on: 03.10.2018. 
URL http://www.planetlyrik.de/kurtbartsch-und-gerhard-melzer-hrsg-alfredkolleritsch/.

Beckermann, T. (1990). Das Labyrinth der Erklärungen: Klaus Hoffers „Bei den Bieresch". The German Quarterly. Vol. 63, 3 (4): 429-436.

Belobratov, A.V. (2007). Which road leads to "The Castle". F.Kafka. The Castle: Novel. SPb: ABC - classics, pp: 470-476.

Borges, J.L. (1962). Fictions. New York: Grove Press, pp: 174.

Bozhkova, G. N., Shastina, E. M., Kalimullina, O. V., \& Shatunova, O. V. (2019). Study of literary images of gifted characters in optional activities as a means to develop capable and talented youth. Space and Culture, India, 7(1), 264-273. doi:10.20896/saci.v7i1.463

Eco, U. (2004). The Open Work: The form and uncertainty in modern poetics. St. Petersburg: Academic Project, pp: 384.

Eco, U. (2014). Six Walks in the Fictional Woods. Trans. from English by A. Glebovskaya. St. Petersburg: Symposium, pp: 285

Friedlander, S. (2016). Franz Kafka: The Poet of Shame and Guilt. Yale University Press, pp: 200.

Gladilin, N.V. (2010). In anticipation of the reader (K. Hoffer's novel "Among the Bieresch" as a postmodern labyrinth"). Questions of Philology, 2(35): 111-121.

Gladilin, N.V. (2012). Posmodernism in the literature of German speaking countries: genesis and the main trends of development: Author's abstract of dis. Doct. Philol., Moscow: MSPU, pp: 36.

Gruber, M. (2004 a). Into the Castle: Novel (Trans. from German by G. Snezhinskaya). St. Petersburg Symposium, pp: 352

Gruber, M. (2004 b). The invention of the new world. M. Gruber. Into the Castle (Trans. from German by G. Snezhinskaya. St. Petersburg: Symposium, pp: 327-348.
Handke, P. (1970). Die Angst des Tormanns beim Elfmeter: Erzählung. Frankfurt am Main: Suhrkamp, pp:155.

Harman, M. (2002). Making Everything "a little uncanny": Kafka's Deletions in the Manuscript of Das Schlo $\beta$ and What They Can Tell Us About his Writing Process', in James Rolleston (ed.), A Companion to the Works of Franz Kafka (Rochester, NY: Camden House,): 325 -346.

Hoffer, K. (2017). Among the Bieresch: A novel (Trans. from German by G. Potapova). St. Petersburg: Symposium, pp: 396.

Hoffer, K. (1986). Methoden der Verwirrung. Betrachtungen zum Phantastischen bei Franz Kafka. Wien, Graz, pp: 152.

Kachorovskaya, A.E. (2010). A new hero and a new reader in the novel by Marianna Gruber "Into the Castle". Izvestia: Herzen State Pedagogical University of Russia, 123:130-134.

Kafka, F. (1991). The Castle: The novel. Novels and parables. A letter to the father. Letters to Milena. Trans. from German. Author. pref. by D. Zatonsky. Moscow: Politizdat, pp: 576.

Kaszynski, S.H. (2017). Österreichische Literatur zwischen Moderne und Postmoderne (Studien zur Germanistik, Skandinavistik und Übersetzungskultur. 17). Frankfurt a. M.: Peter Lang Edition, pp: 203.

Kolleritsch, A. (2003).The Peaches Killers: A seismographic novel (Trans. from German by V. Fadeeva). St. Petersburg: Symposium, pp: 240.

Major, M. (2011). Kafka: For our time: Journeys of Discovery. Harcourt Publishing UK, pp: 202.

Mikhailov, A.V. (2009). Selected works: Phenomenology of Austrian culture. Moscow, St. Petersburg: Publishing House "Center for Humanitarian Initiatives. University book ", pp: 392.

Ortheil, H.-J. (1994). Was ist postmoderne Literatur. Roman oder Leben. 
Postmoderne in der deutschen Literatur. U.Wittstock (Hg.). Leipzig, pp: 125-135.

Plakhina, A.V. (2010). Austrian prose of the late 1970s - early 1990s. History of Austrian literature of the twentieth century. V. II, 1945-2000. Moscow: A.M. Gorky Institute for World Literature and History of Russian Academy of Sciences: pp. 490516.

Sedelnik, V.D. (2009). Franz Kafka. History of Austrian literature of the 20th century. V.1. The end of 19th - the middle of the 20th century. Moscow: A.M. Gorky Institute for World Literature and History of Russian Academy of Sciences: pp. 280309.

Yari, A., Afrougheh, Sh. (2013). Franz Kafka's The Castle: A Foucauldian Reading. International Journal of Literature and Arts. Vol. 1 (3): 63-67.

\section{Acknowledgements}

We would like to thank anonymous reviewers for their comments and recommendations. The work is performed according to the Russian Government Program of Competitive Growth of Kazan Federal University. 